\title{
Histone Deacetylase 10
}

National Cancer Institute

\section{Source}

National Cancer Institute. Histone Deacetylase 10. NCI Thesaurus. Code C104508.

Histone deacetylase 10 (669 aa, $71 \mathrm{kDa}$ ) is encoded by the human HDAC10 gene. This protein plays a role in both the deacetylation of histones and transcriptional regulation. 